\title{
Sampling source heterogeneities that bind the Ontong Java Nui puzzle together
}

\author{
MARIA LUISA GARCIA TEJADA ${ }^{1}$, TAKASHI SANO ${ }^{2}$, \\ TAKESHI HANYU ${ }^{1}$, ANTHONY KOPPERS ${ }^{3}$, MASAO \\ NAKANISHI $^{4}$, AKIRA ISHIKAWA ${ }^{1}$, TAKASHI MIYAZAKI ${ }^{1}$, \\ KENICHIRO TANI $^{2}$, SHOKA SHIMIZU ${ }^{5}$, QING CHANG ${ }^{1}$ \\ AND BOGDAN VAGLAROV ${ }^{1}$ \\ ${ }^{1}$ JAMSTEC \\ ${ }^{2}$ National Museum of Nature and Science \\ ${ }^{3}$ Oregon State University \\ ${ }^{4}$ Graduate School of Science, Chiba University \\ ${ }^{5}$ Graduate School of Science and Engineering, Chiba University \\ Presenting Author: mtejada@jamstec.go.jp
}

The Ontong Java Nui hypothesis, which states that three Pacific oceanic plateaus, Ontong Java, Manihiki and Hikurangi, once conjoined to form a single super plateau has been around for more than a decade now. However, there are critical pieces of the Ontong Java Nui puzzle that either do not fit or are sorely missing. Two of the outstanding inconsistencies are the contrasting crustal thickness between Manihiki Plateau (MP) and Ontong Java Plateau (OJP) and the distinct geochemical composition of Manihiki Plateau tholeiites. During the $\mathrm{R} / \mathrm{V}$ Kairei KR16-04 cruise, we conducted geological surveys and dredging on the ridges protruding from the eastern margin of the OJP, as well as from the capping seamounts. We sampled volcanic rocks that have a variety of geochemical composition ranging from tholeiitic to transitional to alkalic affinities. The tholeiitic to transitional basalts recovered from the capping seamounts show depletion in middle to light rare earth element abundances but have elevated highly incompatible element $(\mathrm{Rb}$, $\mathrm{Th}, \mathrm{Nb}, \mathrm{Ta}$ ) contents. Their trace element patterns resemble the "spoon-shaped" trace element patterns of ultra-depleted tholeiites and glasses from the Danger Island Trough and Suvorov Trough, respectively, on the Manihiki Plateau. The trace element patterns of the ridge samples mimic those of the $44 \mathrm{Ma}, 65 \mathrm{Ma}$, and 90 Ma transitional to strongly alkalic basalts from the Solomon Islands and the Lyra Basin that form the southern and western margins of the OJP, respectively. Indicative older $\sim 96-116 \mathrm{Ma}$ ${ }^{40} \mathrm{Ar}-{ }^{39} \mathrm{Ar}$ ages of the ridge samples dredged near or below the base of the seamounts contrast with the 67-68 Ma plateau ages of flows recovered along the slope of a seamount atop one of the ridges. These ages indicate later formation of the ridges compared to the main OJP ( $122 \mathrm{Ma})$ but match with those of dated samples from Rapuhia Scarp on the northern margin of Hikurangi Plateau. Isotope and trace element data provide the missing compositional link while the new age data tie together the younger ages among Ontong Java, Manihiki and Hikurangi plateau volcanism. These findings support but add complexity to the Ontong Java Nui jigsaw fit. 